\title{
Conceptual design of coastal patrol vessel (CPV) with flight deck for the reception and deployment of helicopter
}

DOI: https://doi.org/10.25043/19098642.214

Miguel Angel Guerrero Sanchez ${ }^{1}$ Edgar Marcelo Cali Yambay ${ }^{1}$

\begin{abstract}
This paper presents the development of the conceptual design of a coastal Patrol vessel with the capacity to receive and deploy a helicopter, in order to increase the efficiency of coastguard operations developed by the Colombian National Navy. As a starting point, the design of the coastal patrol vessel built by Cotecmar and named CPV46 was taken, on which modifications were implemented in its main dimensions and distribution of spaces, which allowed to include a flight deck to receive a BELL 412 EP helicopter, complying with the regulations for this type of operations.

This design was developed based on the design spiral method, where each turn of the spiral includes estimates and performance calculations influenced by each other and corresponding to the different stages of the design. For this work, the conceptual design was divided into eight booklets containing the state of the art, mission profile, capacity sizing, naval architecture, propeller selection, generator selection, stability study and cost estimation, concluding in the feasibility of the design based on its cost at a conceptual level.
\end{abstract}

Key words: Conceptual design, efficiency, design spiral, iterative, mission profile

\section{Resumen}

En este trabajo se presenta el desarrollo del diseño conceptual de un buque Patrullero de costa con capacidad para recibir y desplegar un helicóptero, con el fin de incrementar la eficiencia en las operaciones de guardacostas desarrolladas por la Armada Nacional de Colombia. Como punto de inicio se tomó el diseño del buque patrullero de costa construido por Cotecmar y denominado CPV46, sobre el cual se implementaron modificaciones en sus dimensiones principales y distribución de espacios, lo que permitió incluir una cubierta de vuelo para recibir un helicóptero BELL 412 EP, cumpliendo la reglamentación para este tipo de operaciones.

Este diseño se desarrolló en base al método de la espiral de diseño, donde cada vuelta del espiral incluye estimaciones y cálculos de desempeño influenciadas entre sí y que corresponde a las diferentes etapas del diseño. Para este trabajo se dividió el diseño conceptual en ocho cuadernillos que contienen el estado del arte, perfil de misión, dimensionamiento de capacidades, arquitectura naval, selección del propulsor, selección del generador, estudio estabilidad y estimación de costo, concluyendo en la viabilidad del diseño en base a su costo a un nivel conceptual.

Palabras claves: Diseño conceptual, eficiencia, espiral del diseño, iterativo, perfil de misión. 


\section{Introduction}

The Colombian Navy currently has four CPV coast patrol vessels and four Point Class vessels for coastguard operations, although those Point Class vessels have reached the end of their useful life and are in the process of being discharged. The Colombian Navy has found it necessary to have oceanic patrol vessels (OPVs) and even missile frigates for patrol operations in coastal areas, on sizing capacities for this type of operations and increasing their costs.

"Coastal patrol vessel" project (CPV) with flight deck for the reception and deployment of helicopters, mitigating the oversizing of units used by the Colombian Navy in coastguard operations, such as OPV or missile frigates, increasing the efficiency of these coastguard operations.

\section{Methodology}

The type of descriptive research and the methodology of the design spiral has been highlighted, resulting in a cyclical and iterative method, in which each of the project phases is related to each other, establishing a relationship in each phase of the project. phases, this results in that the concepts and the results in each phase must be verified several times until they adapt to the considerations that keep the phases to each other. In this work a first spin of the spiral is done, which defines a conceptual level of the vessel.

\section{Design Restrictions}

This design was adjusted in compliance with the design standards of the Lloyd's Register Classification Society, in addition to complying with the regulations that regulate nationally and internationally the transit and safety of ships, such as the IMO or MARPOL norms, and the local regulations of the maritime authority DIMAR.

The main restriction of this design falls on the ship's beam, which is wide enough to meet the Lloyd's Register standards for flight decks according to the helicopter it will receive.

Fig. 1. Design spiral, recovered from (Jimenez \& Pino, 2016).

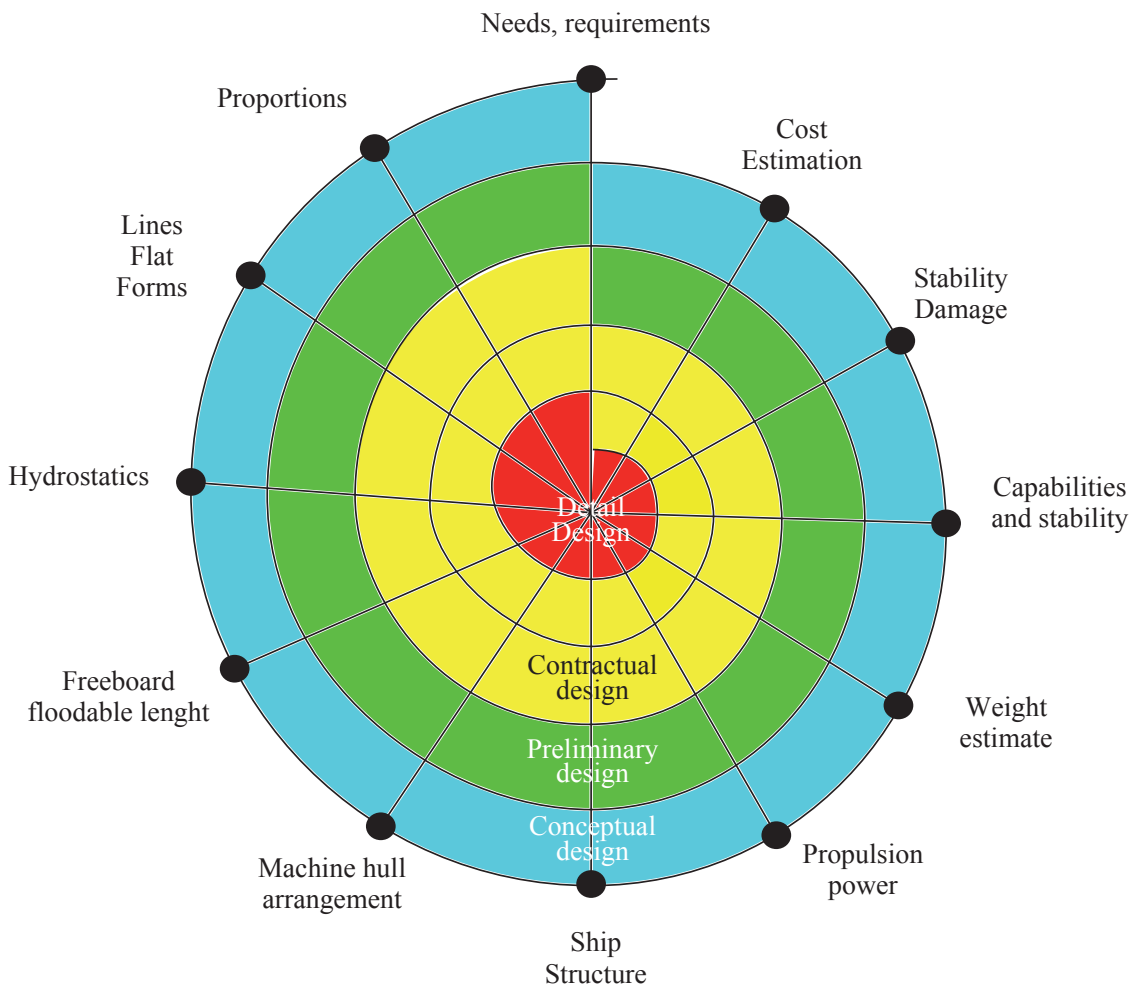


The rotary wing aircraft with which the Colombian Navy has, consist mainly of Bell 412 EP helicopter, so this design was adjusted so that the flight deck can receive this type of aircraft without problems.

\section{Mission Profile}

The coastal patrol vessel should serve as a platform to develop operations of "maritime interdiction, patrolling and surveillance of maritime spaces, and provide support in border control operations to detect, intercept, stop, board, visit and inspect vessels, supply of rapid reaction units, as well as the deployment, taking and supply of boats for visitation and interdiction, "in addition to providing assistance to vessels and people in shipwreck or state of emergency, as required by international conventions (Defensa.com, 2014).

\section{Main Capabilities of the Design}

In this paper, the capacities with which coastal patrol vessel designed and built in Cotecmar (CPV-46) are currently being considered and adjusted, adding the capacities required to receive and deploy a helicopter.

The scope of this conceptual design results in 2000 miles at 12 knots of speed, with a food and water autonomy of 17 days for 23 people.

\section{Characteristics and main dimensions}

The dimensions were determined, taking as a starting point the hull of the CPV-46, designed and built by Cotecmar, in this way the dimensions were adapted so that it could receive a BELL 412 EP helicopter, in Fig. 2 the main dimensions of the BELL 412, of which we take the diameter of rotor of 14.02 meters and the separation between skids of 3.24 meters for the dimensions of the flight deck.

\section{Lines of Form}

Through the MaxSurf Modeler computational tool, a computational model of the CPV hull with flight deck is developed, obtaining the next forms:

Fig. 2. Planos Bell 412 EP (Textron Company, 2006).
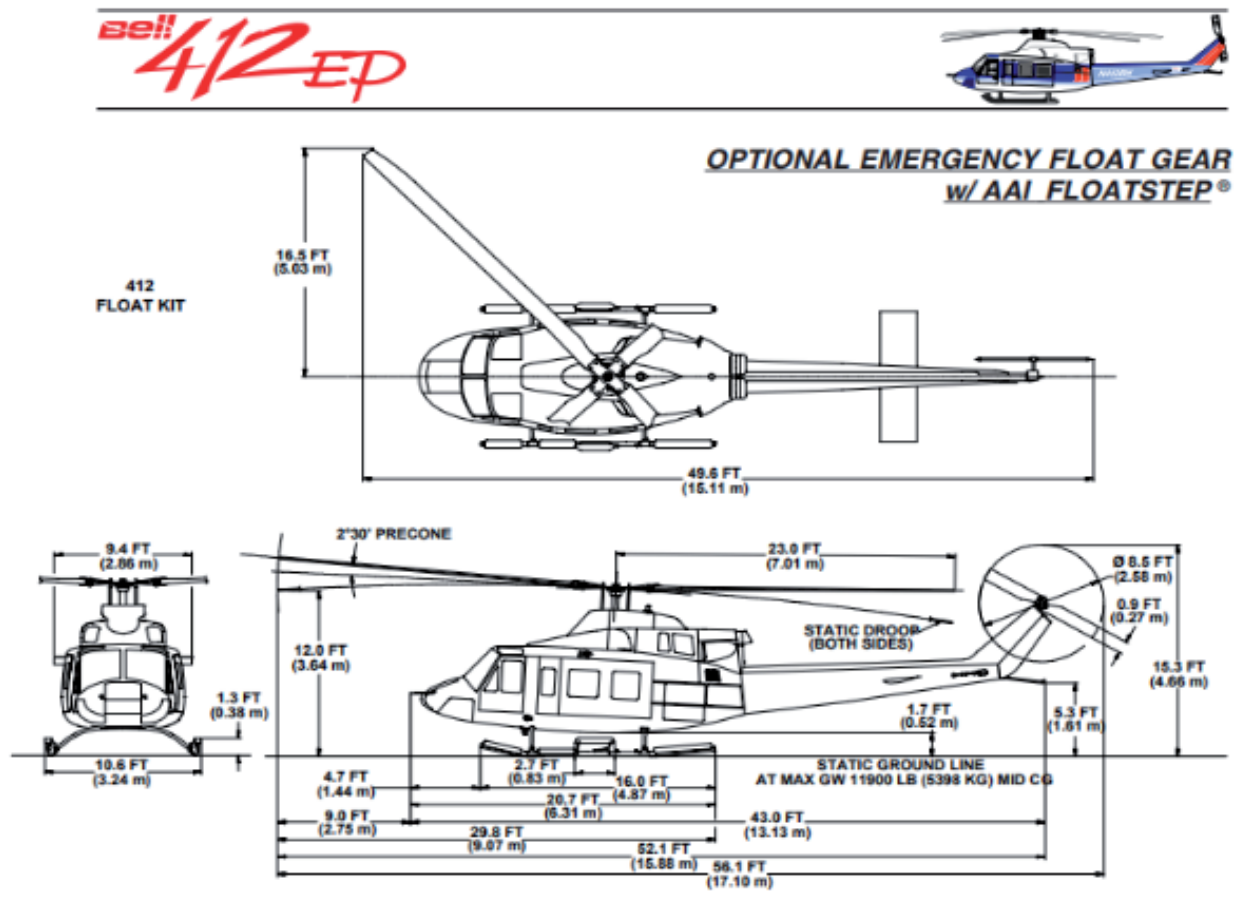
Fig. 3. Lines of forms.

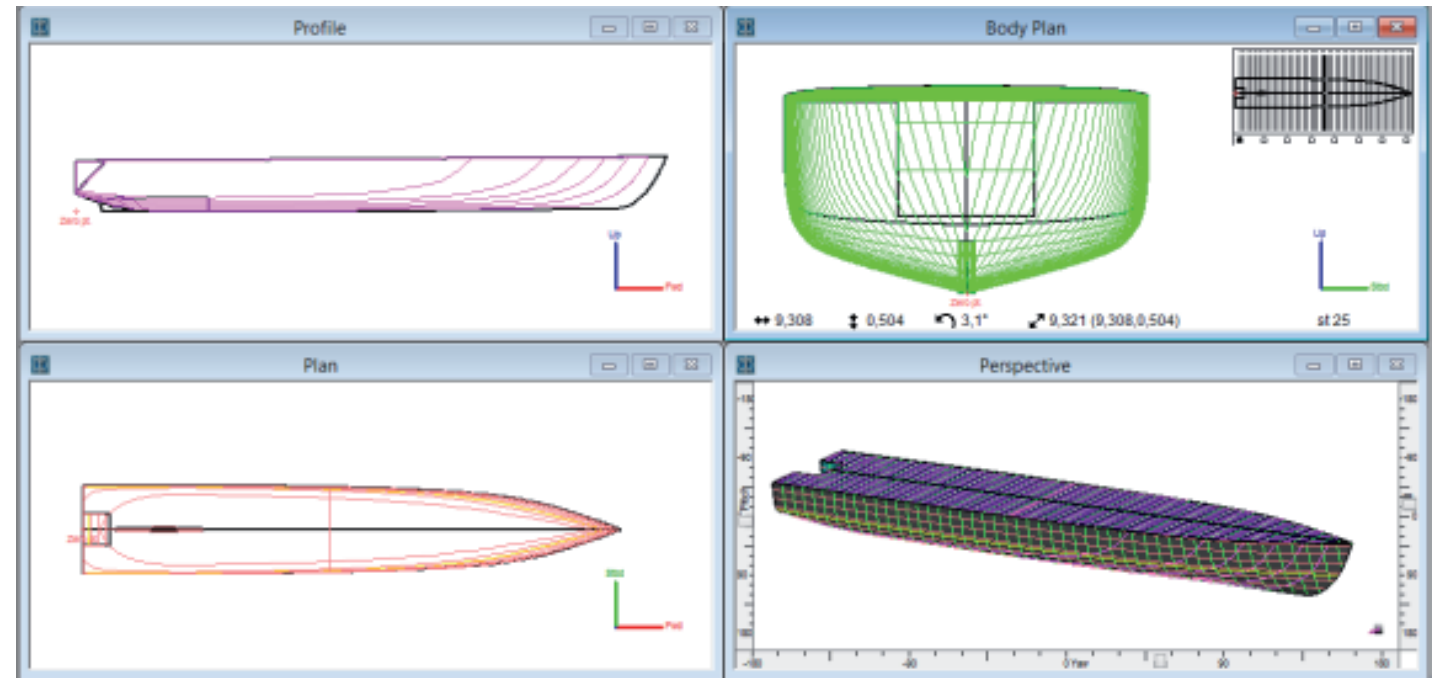

Table 1. Dimensions and general characteristics of this design.

\begin{tabular}{|c|c|c|}
\hline Lenght & 49 & [Meters] \\
\hline Breadth & 8 & [Meters] \\
\hline Depth & 4,56 & [Meters] \\
\hline Draught & 2,1 & [Meters] \\
\hline Displacement & 414,7 & [Ton] \\
\hline Cruise speed & 12 & [Knot $]$ \\
\hline Maximum speed & 19 & [Knot] \\
\hline
\end{tabular}

\section{Power Estimation}

By means of the computer tool MaxSurf Resistance, the resistance to advance of the computational model of the hull between 6 and 19 knots is estimated, obtaining the results shown in Table 2.

From the result presented in the previous table, the $15 \%$ resistance of appendices that we assume has this design is added resulting in a resistance of 216, $66 \mathrm{KN}$ for 19 Knots of speed.

The effective power (PE) is the result from multiplication the resistance estimated in $\mathrm{KN}$ by the speed in $\mathrm{m} / \mathrm{s}$, from here the brake power $(\mathrm{PB})$ required by the propulsion engines is estimated, resulting from a margin of $90 \%$ aging and a propulsive efficiency assumed in $60 \%$ of the effective power (PE), as shown in Table 3.

\section{Dimensioning of Tanks}

Knowing the fuel and lubricant consumption of the propulsion engines and generators, the tank capacity is estimated considering the reach of 2000 nautical miles at $12 \mathrm{Kn}$ and the autonomy of 17 days for 23

Table 2. Resistance to advance.

\begin{tabular}{|c|c|c|}
\hline $\begin{array}{l}\text { Vel } \\
\text { (Knt) }\end{array}$ & $\begin{array}{l}\text { Froude No. } \\
\text { (LWL) }\end{array}$ & $\begin{array}{l}\text { Holtrop Resist } \\
\text { (KN) }\end{array}$ \\
\hline 6 & 0,143 & 7 \\
\hline 7 & 0,167 & 9,4 \\
\hline 8 & 0,19 & 12,4 \\
\hline 9 & 0,214 & 16,3 \\
\hline 10 & 0,238 & 21,3 \\
\hline 11 & 0,262 & 27,4 \\
\hline 12 & 0,286 & 36,3 \\
\hline 13 & 0,309 & 48,3 \\
\hline 14 & 0,333 & 57,5 \\
\hline 15 & 0,357 & 65,1 \\
\hline 16 & 0,381 & 76,9 \\
\hline 17 & 0,405 & 101 \\
\hline 18 & 0,428 & 144,6 \\
\hline 19 & 0,452 & 188,4 \\
\hline
\end{tabular}


Table 3. Power estimation.

\begin{tabular}{|c|c|c|c|}
\hline Vel (Knt) & $\begin{array}{c}P E \text { with service } \\
\text { margin }(K W)\end{array}$ & $\begin{array}{c}\mathrm{PB}(\mathrm{KW}) \\
\eta p=0,6\end{array}$ & $\begin{array}{c}\text { PB total }(\mathrm{KW}) \\
\text { MCR }=90 \%\end{array}$ \\
\hline 6 & 28,550 & 47,584 & 52,871 \\
\hline 7 & 44,729 & 74,548 & 82,831 \\
\hline 8 & 67,433 & 112,388 & 124,875 \\
\hline 9 & 99,722 & 166,203 & 184,669 \\
\hline 10 & 144,790 & 241,317 & 268,130 \\
\hline 11 & 204,881 & 341,469 & 379,410 \\
\hline 12 & 296,106 & 493,509 & 548,344 \\
\hline 13 & 426,824 & 711,374 & 790,416 \\
\hline 14 & 547,211 & 912,018 & 1013,353 \\
\hline 15 & 663,791 & 1106,318 & 1229,242 \\
\hline 16 & 836,383 & 1393,971 & 1548,857 \\
\hline 17 & 1167,157 & 1945,261 & 2161,401 \\
\hline 18 & 1769,292 & 2948,821 & 3276,467 \\
\hline 19 & 2433,287 & 4055,478 & 4506,087 \\
\hline
\end{tabular}

people, this taking into account the fact that Water and fuel pumps do not suck a remaining $10 \%$ of the tanks and the tanks are not filled to more than 95\% to prevent them from overflowing. Estimate the minimum tank capacity resulting in the next table.

Table 4. Minimum capacity of tanks of this design.

\begin{tabular}{|c|c|}
\hline Fluid & Volume $\left(\mathbf{m}^{3}\right)$ \\
\hline Water & 13,8 \\
\hline Fuel & 33,78 \\
\hline Lubricant Oil & 1,79 \\
\hline
\end{tabular}

From the previous information, the tanks are dimensioned with the MaxSurf Stability computational tool, resulting in the next distribution of tanks:

Table 5. Tank capacity of this design.

\begin{tabular}{|c|c|c|}
\hline Fluid & Volume $\left(\mathbf{m}^{3}\right)$ & Weight (Ton) \\
\hline Water & 14,856 & 14,856 \\
\hline Fuel & 34,138 & 28,678 \\
\hline Lubricant Oil & 2,029 & 1,867 \\
\hline Hydraulic oil & 0,538 & 0,495 \\
\hline URR gasoline & 7,14 & 5,354 \\
\hline Gasoline Helicopter & 7,14 & 5,354 \\
\hline Grey waters & 3,043 & 2,778 \\
\hline Sewage water & 3,043 & 2,778 \\
\hline
\end{tabular}

\section{Study of Weights and Definition of The Gravity Center Of The Vessel In Lightship}

This design used the cubic number (NC) method, which maintains a ratio of length $\mathrm{x}$ breadth $\mathrm{x}$ depth between two vessels, keeping a real reference to develop the estimate of a design. Knowing the dimensions and loads of the CPV-46, the study of weight in the condition of displacement light ship or also known as thread weight was developed, estimating the load distribution and center of gravity of this design (CPV-49), with a margin of error of $3 \%$ in this displacement condition, resulting in what is presented in Table 6 .

\section{Study of Dead Weight}

The dead weight represents the load carried by the vessel and the contents of their tanks, whether water, oil, fuel, ballast, crew, food, etc. For this design, the helicopter that will be located on the flight deck and the contents of the water, ballast and fuel tanks are considered deadweight.

Below is the distribution of the deadweight quantities for this design, fulfilling the 
Table 6. Light ship distribution of this design.

\begin{tabular}{|c|c|c|}
\hline SWBS & Description & $\begin{array}{l}\text { Weight } \\
\text { (ton) }\end{array}$ \\
\hline \multirow{3}{*}{100} & Hull and structur & 135,06 \\
\hline & Superstructur & 16,09 \\
\hline & Flight deck & 5,00 \\
\hline 200 & Propultion & 40,17 \\
\hline 300 & Electric plant & 20,97 \\
\hline 400 & Control and command & 4,87 \\
\hline \multirow{2}{*}{500} & Auxiliary systems & 32,46 \\
\hline & Helicopter sistems & 1,00 \\
\hline 600 & Acomodations & 62,03 \\
\hline \multirow[t]{5}{*}{700} & Armament & 11,12 \\
\hline & Lead & 2,56 \\
\hline & Total & 331,32 \\
\hline & Margin 3\% & 9,94 \\
\hline & Light ship & 341,26 \\
\hline
\end{tabular}

minimum total tank capacities estimated previously and according to the distribution of Maxsurf Stability tanks and the number of crew established for this design.

Table 7. Deadweight distribution of this design.

\begin{tabular}{lr}
\hline \multicolumn{1}{c}{ Features } & \multicolumn{1}{c}{ Weight (Ton) } \\
\cline { 1 - 2 } Helicopter & 5,4 \\
\hline Crew & 1,8 \\
\hline Food & 3 \\
\hline Load & 2,988 \\
\hline Content tanks & 60,212 \\
\hline Total & 73,4 \\
\hline
\end{tabular}

\section{Study of Transversal Stability}

For this design the stability study was developed for three (03) loading conditions, maximum displacement, half load and light ship, by means of the MaxSurf Stability computational tool, these load conditions were simulated, obtaining positive results in the required criteria. by the IMO stipulated in chapter three of resolution A 749 "Intact stability without damage code ", which apply to vessels over 24 meters in length.

\section{Scantling}

This design was developed following the rule of Lloyd's Register, "Rules and Regulations for classification of Naval Ship" of 2018, where it is established as an initial step to determine the type of vessel that is being designed according to the standard, as a result this category was categorized. design as a NS3 type, this category covers ships with less than 1500 tons displacement and with frontline roles that can operate individually or in a group of operations, corresponding to ships for mine sweeping, landing on beaches, coastal defense or fast patrol boat.

The construction materials were selected for this design, taking as reference the materials used in the CPV-46.

Table 8. Building materials (STX, 2014).

\begin{tabular}{lll}
\hline \multicolumn{1}{c}{ Location } & \multicolumn{1}{c}{ Material } \\
\cline { 1 - 2 } Hull & Steel ASTM AH32 \\
\hline Super-structure & Aluminum A 5083 \\
\hline
\end{tabular}

For the NS3 category certain guidelines are preserved for the development of the estimation and calculation of the scantling, such as the minimum plate thicknesses and the moments of inertia of the structural reinforcements, resulting in the following master frame.

Fig. 4. Main frame scantling.

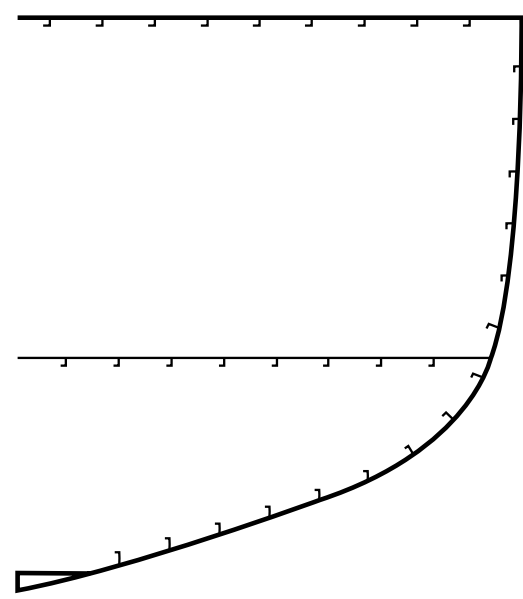


Table 9. Dimensions structural elements of the master frame.

\begin{tabular}{|c|c|}
\hline Structural elements & Dimensions \\
\hline Deep plate & thickness $9,525 \mathrm{~mm}$ \\
\hline Bilge plate & thickness $9,525 \mathrm{~mm}$ \\
\hline Side plate & thickness $6,35 \mathrm{~mm}$ \\
\hline Deck 2 plate & thickness $6,35 \mathrm{~mm}$ \\
\hline Principal deck plate & thickness $6,35 \mathrm{~mm}$ \\
\hline Reinforce keel core & thickness $9,525 \mathrm{~mm}$ \\
\hline Reinforce keel wing & thickness $9,525 \mathrm{~mm}$ \\
\hline Longitudinal reinforce deep & Angle $80 \times 40 \times 8$ \\
\hline Longitudinal reinforce bilge & Angle $80 \times 40 \times 8$ \\
\hline Longitudinal reinforce sides & Angle $50 \times 50 \times 8$ \\
\hline Longitudinal reinforce deck 2 & Angle $50 \times 50 \times 8$ \\
\hline Longitudinal reinforce principal deck & Angle $50 \times 50 \times 8$ \\
\hline
\end{tabular}

The module of section of the master frame was estimated and compared with the minimum of module section that according to the International Association Classification Society (IACS) (Ávila, 2018) for the dimensions of this design, resulting in the following.

Table 10.

\begin{tabular}{rr}
\hline $\begin{array}{c}\text { Master frame section } \\
\text { module }\end{array}$ & $\begin{array}{c}\text { Minimum of module } \\
\text { section according to IACS }\end{array}$ \\
\hline $0,2858 \mathrm{~m}^{3}$ & $0,1161 \mathrm{~m}^{3}$ \\
\hline
\end{tabular}

We estimate the maximum bending moment that the master frame supports according to its section modulus and the creep stress of the construction material $\left(M_{\max }=Z^{*} \sigma_{0}\right)$, resulting in $M_{\max }=90027$ $K N^{*} m$.

According to (Avila, 2018) the maximum bending moment that the master frame can support, must be greater than the bending moment calculated according to the IACS, which adds a bending moment in calm waters $\left(M_{s w}\right)$ and a bending moment in waves $\left(M_{W_{2}}\right)$.

The bending moment in calm waters includes the concept of the ship beam, where the total of the structure of the ship is taken as a beam, this ship beam according to the global and local loads to which it is subjected generates certain shear stresses and moments bending, in the maximum bending moment produced in the ship beam is taken as the bending moment in calm waters, which can be found by means of the MaxSurf Stability computational tool, resulting in an $M_{s w(-)}$ ) $=11424,76 \mathrm{KN}^{*} m$ in shear.

The moment in waves $\left(M_{W_{v}}\right)$ is separated into two types of moments, moment in waves by grief or moment in waves by sheer, estimating the two directions in which the ship can be flexed longitudinally. The moments in waves are calculated from the next formulas and then added to the moment in calm waters to determine the maximum moment according to IACS (Ávila, 2018).

Grief:

$$
\begin{aligned}
& M_{w v(+)}=0,19 * M * C * L_{W L}^{2} * B * C_{B} \\
& M_{w v(+)}=12023,95 K N * m \\
& M_{I A C S}=M_{s w}+M_{w v(+)}=599,19 K N * m \\
& M_{I A C S}=599,19 K N * m
\end{aligned}
$$

Sheer:

$$
\begin{aligned}
& M_{w v(-)}=0,11 * M * C * L_{W L}^{2} * B * C_{B} \\
& M_{w v(-)}=6961,234 K N * m \\
& M_{I A C S}=18385,994 K N * m
\end{aligned}
$$


According to the previous results, we can conclude that the master frame complies with the capabilities to withstand the ship's loads at sea.

\section{Vertical Speeds on the Flight Deck}

According to the Lloyd's Register standard, the maximum permissible vertical speeds for a flight deck in a design according to the state of the sea at the Douglas scale are in the next table:

Table 11. Vertical Velocity (Lloyd's Register, 2018).

\begin{tabular}{|c|c|}
\hline Sea state & $\begin{array}{l}\text { Vertical velocity } \\
(\mathrm{m} / \mathrm{s})\end{array}$ \\
\hline 6 & 3,72 \\
\hline 5 & 3,35 \\
\hline 4 & 2,97 \\
\hline 3 & 2,60 \\
\hline 2 & 2,23 \\
\hline
\end{tabular}

With the Maxsurf Motion computational tool (Bentley Engineering), the sea behavior of the computational model of this design was simulated, according to the Douglas scale, these simulations were developed for a sea 4 and a sea 5 for the Caribbean Sea region, with a modal period and a height of the wave as presented in the next table:

Table 12. Sea conditions in MaxSurf Motion computer simulation.

\begin{tabular}{|c|c|c|}
\hline $\begin{array}{l}\text { State of the sea } \\
\text { (Caribbean) }\end{array}$ & $\begin{array}{l}\text { Wave height } \\
\text { (m) }\end{array}$ & $\begin{array}{l}\text { Modal period } \\
\text { (s) }\end{array}$ \\
\hline 4 & 1,7 & 6,515 \\
\hline 5 & 2,6 & 9,062 \\
\hline
\end{tabular}

According to the results of this simulation of the computational model, it is observed that the Lloyd's Register standard is satisfactorily fulfilled, as presented in the next table.

Table 13. Summary result vertical speeds on the flight deck.

\begin{tabular}{|c|c|c|}
\hline $\begin{array}{l}\text { State of the } \\
\text { sea }\end{array}$ & $\begin{array}{c}\text { Maximum } \\
\text { admissible values }\end{array}$ & $\begin{array}{c}\text { Minimum value } \\
/ \text { maximum } \\
\text { obtained }\end{array}$ \\
\hline Sea 4 & 2,97 & $0,126 / 0,494$ \\
\hline Sea 5 & 3,35 & $0,222 / 0,785$ \\
\hline
\end{tabular}

\section{Conclusions}

During the development of this design, the proposed objectives were achieved through the phases mentioned in the research methodology.

It was determined that the minimum length to include in the design of the CPV-46 a flight deck, is 49 meters according to the "Rules and Regulations for the classification of Naval Ship" standard of the Lloyd's Register Classification Society, in addition to reduce the maximum speed from 20 Knots to 19 Knots, because it would require that each propeller engine had more than $1300 \mathrm{KW}$ of power to be able to achieve that single knot of difference, increasing much more the maximum displacement and the need for tank capacity made out of fuel.

During the development of this design, it was observed that for a breadth of 7.5 meters (initial breadth with which this design was estimated) favorable results were not obtained in their transverse stability, for which an 8 meter breadth was determined to counteract this situation, offering favorable results in the study of stability.

\section{References}

ALBERTO GRANADA LÓPEZ, P. H. (2017). Informe de la estimación de la distorsión en el valor de las importaciones colombianas. Dreccion de Impuestos y Aduanas Nacional.

ÁVILA, B. (2018). Notas de clase de "Estructura del Buque", curso Ingeniería Naval. Cartagena: Escuela Naval Almirante Padilla.

BENTLEY ENGINEERING. (s.f.). Maxsurf 20 V8i.

BLANCO, J. M. Proceso de Construcción de un Buque. En J. M. Blanco, LA CONSTRUCCION NAVAL (págs. 63-64).

BRAKHAGE, M. (10 de Mayo de 2011). Zarpa hacia Colombia, la nueva patrullera de costa ARC 11 de Noviembre. Recuperado el 01 de Junio de 2018, de Webinfomil.com: http:// 
www.webinfomil.com/2011/05/zarpa-haciacolombia-la-nueva.html

Buque Patrullero. (28 de Julio de 2008). Recuperado el 01 de Junio de 2018, de Wikipedia: https:// es.wikipedia.org/wiki/Buque_patrullero

CATERPILLAR. (s.f.). 3516C HD MARINE PROPULSION. Recuperado el 20 de OCTUBRE de 2018, de CATERPILLAR : http://www.teknoxgroup.com/fileadmin/user_ upload/3516C_-_HD.pdf

CATERPILLAR. (s.f.). CAT C4.4 Diesel Engine. Recuperado el 21 de Octubre de 2018, de Gecolsa: https:/gecolsa.com/uploads/product/ equipment/brochure/C4.4_-_72.4-111.3bhp. pdf

CATERPILLAR. (s.f.). Propulsores marinos. Recuperado el 10 de otubre de 2018, de finanzauto: http://www.finanzauto.es/es/ productos/soluciones-energeticas-y-depropulsion/marino/propulsores

CENTRO INTERNACIONAL MARITIMO DE ANALISISCONTRAELNARCOTRÁFICO. (2016). Análisis eventos presentados contra el narcotrafico en la region I trimestre.

DANE. (s.f.). Departamento Administrativo Nacional de Estadísticas. Recuperado el 28 de Octubre de 2018, de DANE: http://www.dane.gov.co/ index.php/52-espanol/noticias/noticias/4026indice-de-precios-al-consumidor-ipc-ano-2016y-diciembre-2016

Defensa.com. (4 de Noviembre de 2014). Botado en Colombia el ARC "Punta Espada". Recuperado el 10 de Junio de 2018, de Defensa.com: https:// www.defensa.com/colombia/botado-colombiaarc-punta-espada

EL UNIVERSAL. (27 de Julio de 2016). Asi será la Armada Nacional en 2030. Recuperado el 30 de Marzo de 2018, de El Universal: http:// www.eluniversal.com.co/colombia/asi-sera-laarmada-nacional-en-2030-231543
EL UNIVERSAL. (31 de Octubre de 2014). Bautizan primer buque patrullero de costa construido en Colombia. Recuperado el 30 de Marzo de 2018, de El Universal Cartagena: http://www.eluniversal.com.co/cartagena/ bautizan-primer-buque-patrullero-de-costaconstruido-en-colombia-175580

FUENTES, D. (2018). Estimación de potencia. Notas de clase, Resistencia al Avance, docente CC Fuentes David. Cartagena.

GARCIA. (6 de Enero de 2013). Nuevos Helicópteros Bell 412 Para la Armada Nacional. Recuperado el 10 de Junio de 2018, de Webinfomil: http:// www.webinfomil.com/2013/01/nuevoshelicopteros-bell-412-para-la.html

GARCIA. (10 de Mayo de 2011). Zarpa hacia Colombia, la nueva patrullera de costa ARC 11 de Noviembre. Recuperado el 01 de Junio de 2018, de Webinfomil.com: http://www.webinfomil. com/2011/05/zarpa-hacia-colombia-la-nueva. html

HOLGUIN CUELLAR, M. A. (2013). Labores cumplidas durante el período comprendido entre junio de 2012 y junio de 2013 y el estado de los negocios adscritos a este ministerio. Conforme al Artículo 208 de la Constitución Nacional. En M. A. Cuellar, Memorias al Congreso 2012-2013 (pág. 30). Cancilleria, ministro de relaciones exteriores.

JIMENEZ, N., \& PINO, J. (2016). Recuperado de Diseño Conceptual Buque Tipo CPV para el Pacifico. Cartagena: Escuela Naval de Cadetes Almirante Padilla.

LabSI INVEMAR. (2009). Colombia 50\% Mar. Recuperado el 10 de Junio de 2018, de Invemar: http://www.invemar.org.co/50-mar

LLOYD'S REGISTER. (2018). Parte 3 "Main Hull Structure". En Lloyd's Register, Rules and Regulations for the classification of Naval Ship (págs. 75-209). Lloyd's Register. 
LLOYD'S REGISTER. (2016). Geometric Properties of Rolled Sections. En Lloyd's Register, Rules and Regulations for the classification of Inland Waterways Ships (págs. 65-66). Lloyd's Register.

LLOYD'S REGISTER. (2018). Part 1 Regulations, Volumen 1 Ship Structures. En L. Register, Rules and Regulations for the classification of naval ship (pág. 11). Lloyd's Register.

LLOYD'S REGISTER. (2018). Parte 5 "Environmental Conditions". En Lloyd's Register, Rules and Regulations for the classification of Naval Ship (págs. 301- 374). Lloyd's Register.

LLOYD'S REGISTER. (2018). Parte 6 "Hull Construction in Stell". En Lloyd's Register, Rules and Regulations for the classification of Naval Ship (págs. 378-539). Lloyd's Register.

LLOYD'S REGISTER. (2018). plating general. En Lloyds Register, Rules anf regulations for the classification of naval ship (pág. 387). Lloyd's Register.

LLOYD'S REGISTER. (2018). Rules and Regulations fot the classification of naval ship. En L. Register, Military Load Specification Volumen 1, Part 4, Chapter 2, Section 5 (pág. 253). Lloyd's Register.

LLOYD'S REGISTER., C. C. (2018). Rules and Regulations for the Classification of Naval Ships. Lloyd's Register.
REVISTA DINERO. (1 de Marzo de 2018). Costo de Vida. Recuperado el 28 de Octubre de 2018, de Revista Dinero: https://www.dinero.com/ economia/articulo/inflacion-total-de-2017-encolombia-ipc/253916

STX, O. \&. (30 de 10 de 2014). Planos Costal Patrol Vessel. Planos CPV - 46. Corea del Sur.

TEXTRON COMPANY. (2006). Bell 412 EP, product specifications. Textron Company.

WEBINFOMIL. (31 de Marzo de 2015). ARC Punta Ardita y ARC Punta Soldado fortalecen la seguridad maritima de Colombia. Recuperado el 10 de Junio de 2016, de Webinfomil.com: http://www.webinfomil.com/2015/03/arcpunta-ardita-y-arc-punta-soldado.html

WEBINFOMIL. (3 de Noviembre de 2014). ARC Punta Espada, primer buque patrullero costa CPV-46 construido en Colombia. Recuperado el 10 de Junio de 2018, de Webinfomil. com: http://www.webinfomil.com/2014/11/ arc-punta-espada-cpv-46-armada-colombiacotecmar.html

WEBINFOMIL. (5 de Octubre de 2018). Armada de Colombia retiró del servicio al buque patrullero ARC "Cabo Corrientes". Recuperado el 13 de Octubre de 2018, de Webinfomil.com: http:// www.webinfomil.com/2018/10/armada-decolombia-retiro-del-servicio.html 